\title{
NOTE
}

\section{Aluterus monoceros (ACANTHOPTERYGII, TETRAODONTIFORMES) SOUTHWARDS DISTRIBUTION RANGE EXTENSION IN ARGENTINE WATERS}

\author{
Andrés C. Milessi ${ }^{1,2}$ Ignacio Bruno $^{1}$, Ezequiel Cozzolino ${ }^{1}$ and Rodrigo WifF ${ }^{3}$ \\ ${ }^{1}$ Instituto Nacional de Investigación y Desarrollo Pesquero (INIDEP), \\ Paseo Victoria Ocampo No 1, Escollera Norte, B7602HSA - Mar del Plata, Argentina \\ e-mail: acmm@inidep.edu.ar \\ ${ }^{2}$ Comisión de Investigaciones Científicas de la Provincia de Buenos Aires (CIC), Argentina \\ ${ }^{3}$ Center of Applied Ecology and Sustainability (CAPES), Facultad de Ciencias Biológicas, \\ Pontificia Universidad Católica de Chile, Santiago, Chile
}

\begin{abstract}
The presence of Aluterus monoceros (Linnaeus, 1758) in Mar del Plata, Argentina ( $\left.38^{\circ} \mathrm{S}\right)$ was registered over 40 years ago. This new report extends its southernmost distribution limit to $39^{\circ} \mathrm{S}$ (Necochea: $\sim 120 \mathrm{~km}$ ). The presence of the species could be associated to the warm subtropical water derived from the Brazilian continental shelf. The hypothesis was tested with satellite images of the sea surface temperature recorded during the cruise the specimen was caught.
\end{abstract}

Key words: Unicorn leatherjacket filefish, geographical distribution, Monacanthidae.

Unicorn leatherjacket filefish, Aluterus monoceros (Linnaeus, 1758) distributes in subtropical and warm temperate zones worldwide (Froese and Pauly, 2015). In the Atlantic Ocean it is usually reported from New England (USA) to Southern Brazil ( $\left.32^{\circ} \mathrm{S}\right)$, including the Caribbean Sea (Carvalho-Filho 1999; Figueiredo and Menezes 2000). The species, that feeds mainly on crustaceans, sponges, algae and corals, of $750 \mathrm{~mm}$ maximum length reported, is associated to coral and rocky reefs found up to $150 \mathrm{~m}$ depth (Carvalho-Filho 1999; Bernardes et al. 2005; Froese and Pauly 2015). Its presence off Mar del Plata (38 S) Argentina, was registered only once, over 40 years ago (Cousseau and Bastida 1976). The objective of this note is to document Aluterus monoceros southwards geographical extension from the limit previously reported.

During a fishing operation carried out from $20^{\text {th }}$ through $22^{\text {nd }}$ January 2014, a unicorn leather- jacket filefish specimen was caught on board of the "Angela" bottom trawler off Necochea coastal area $\left(\sim 39^{\circ} 00^{\prime} \mathrm{S}-58^{\circ} 40^{\prime} \mathrm{W}\right)$ at $20 \mathrm{~m}$ depth in a rocky-sandy sediment area. The specimen was photographed, weighted, measured and sexed at the laboratory, identified following Berry and Vogele (1961) and preserved in the ichthyologic collection of the Instituto Nacional de Investigación y Desarrollo Pesquero (INIDEP) under number INIDEP 852 (Figure 1). The sea surface temperature (SST) was determined processing Aqua-MODIS $4 \mathrm{~km}$ resolution satellite images from: http//oceancolor.gsfc.nasa.gov when the fish was caught (Figure 2).

The individual, a 1,212.2 $\mathrm{g}$ weight $511 \mathrm{~mm}$ total length (TL) mature male (maturity stage IV) presented one hard dorsal spine, 49 soft rays in second dorsal fin and 47 anal fin rays considered the species diagnostic characters (Berry and Vogele 1961) and rough, dark brown skin with tiny thorns 
and dark spots. The SST indicated waters warmer than $22^{\circ} \mathrm{C}$ related to the advection of oceanic warm waters to the coast produced by a favourable wind pattern from the North. Its horizontal distribution showed the presence of warm waters all over the Argentine shelf during Summer 2014.

The characteristics mentioned agree with the descriptions of $A$. monoceros Brazilian specimens by Berry and Vogele (1961), Carvalho-Filho (1999), and Figueiredo and Menezes (2000).

The first record of A. monoceros in Argentine waters published by Cousseau and Bastida (1976) was based on an individual (508 mm TL) caught on $27^{\text {th }}$ April 1976 in Mar del Plata (38 $\left.\mathrm{S}\right)$. The new report extends the species previously known range in $\sim 120 \mathrm{~km}$ to the South. Neither the first record produced in 1976 nor the scarce information provided by INIDEP on different surveys reported further analyses about sex, maturity stage or weight. The SST result is compatible to the process that forms the Subtropical Shelf Water (STSW), a mix between the Plata Plume Water and Tropical Waters (Moller et al. 2008). Said oceanographic process is known as warm coastal drift (Balech 1986; Balech and Ehrlich 2008) and is common in Argentine waters during austral Summer and Autumn, when winds coming from the north and north-east become stronger (Guerrero et al. 1997; Martos and Piccolo, 1998). The
STSW flow allows the arrival of subtropical and tropical fishes to Mar del Plata, Argentina (Cousseau and Figueroa 1989; Figueroa et al. 1992, 2000; Izzo et al. 2009; Milessi et al. 2012, 2017).

A. monoceros new report constitutes another piece of information supporting the hypothesis that the warm coastal drift allows changes in tropical and subtropical fishes distribution that, due to an increase in water temperature, show a true southwards expansion (Ortega et al. 2016) . During the last decade high abundance reports of commonly unusual species such as Epinephelus marginatus and Hyporthodus niveatus (Irigoyen et al. 2005; Trobbiani et al. 2014; Milessi et al. 2018) off Argentina and Stellifer rastrifer in Uruguay (Segura et al. 2008) suggest colonization and establishment of new distribution areas. To assess said hypothesis a time series analysis of new species is needed. Correlations between new species records and changes in other environmental variables may help understand the causes for the reported distribution expansion. Data about displacement of subtropical and tropical species as a result of global warming may contribute new records (Scenna et al. 2006; Venerus et al. 2007) supporting the hypothesis that southwards expansion of said species off Mar del Plata is favoured by the increase of water temperature.

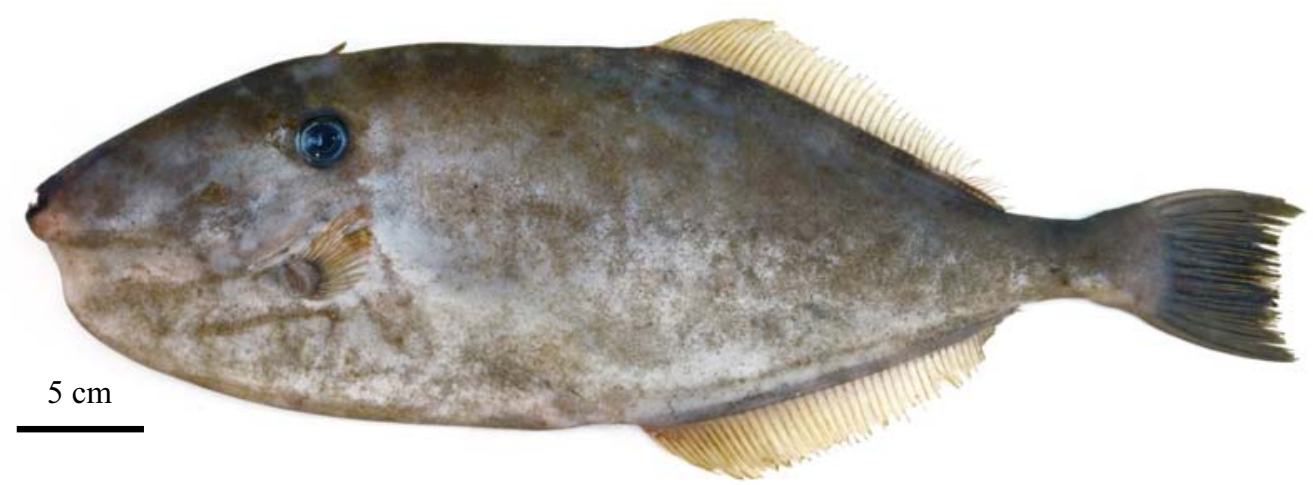

Figure 1. Aluterus monoceros (Linnaeus, 1758); INIDEP fish collection no. 852. Total length: 511 mm; weight: $1,212.2$ g. Photo by Marcela Tobio. 


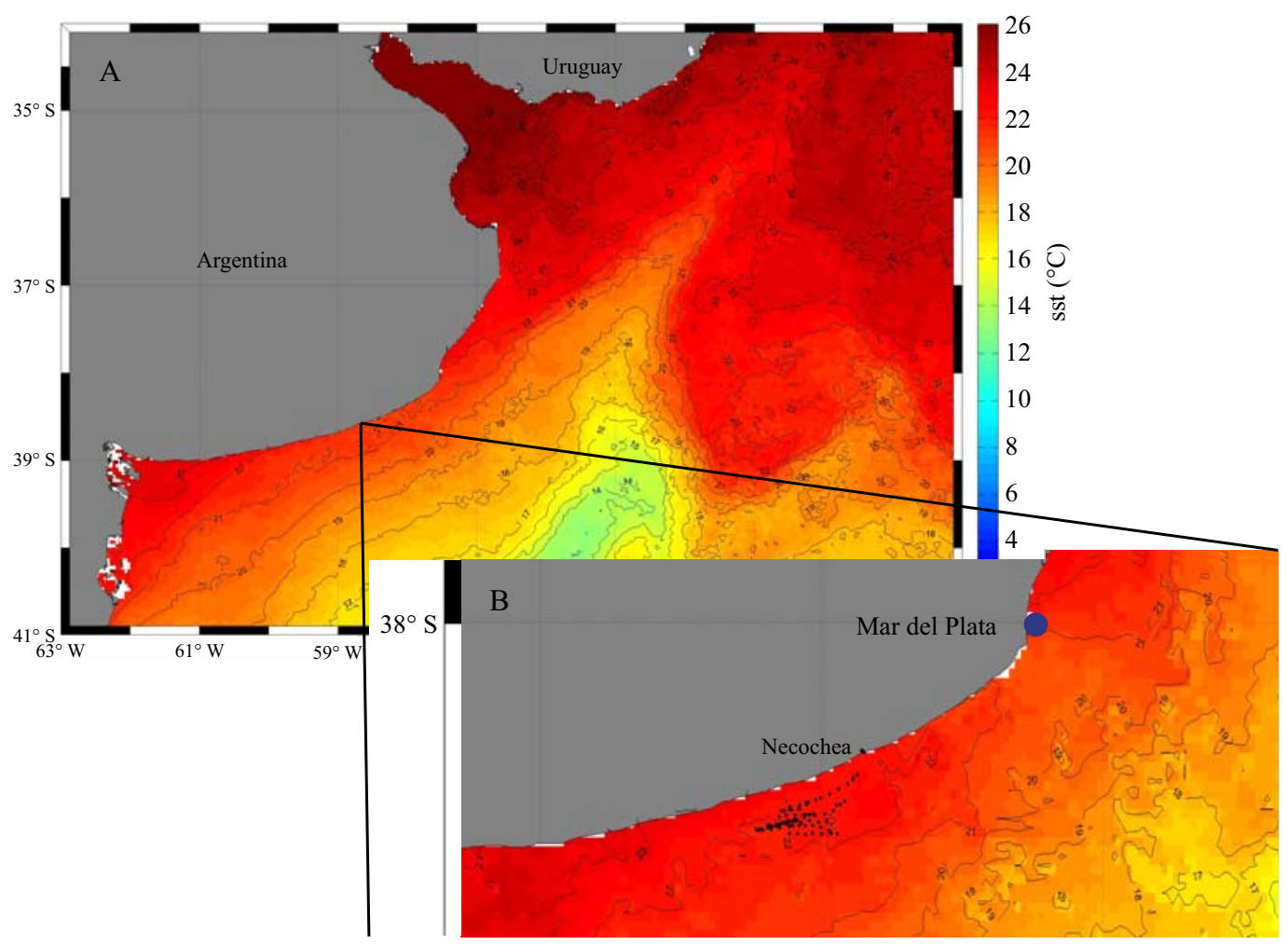

Figure 2. Sea surface temperature $\left({ }^{\circ} \mathrm{C}\right)$ from the Argentine-Uruguayan Coastal Ecosystem, $34^{\circ} \mathrm{S}-41^{\circ} \mathrm{S}$ (Aqua MODIS, $4 \mathrm{~km}$ ) (A) and the site where the specimen was caught near Necochea port ( $\left.38^{\circ} 32^{\prime} \mathrm{S}\right)$ (B). The black dots indicate the fishing trawls performed during the trip in which the specimen was caught ("Angela" FV). The blue point indicates the only previous record of Aluterus monoceros in Argentine waters (Mar del Plata port).

We are grateful to the "Angela" FV fishermen (Pablo, Julio, Ariel and Gaby) who caught the specimen; to M. Tobio for the photographs; to Dr. A. Carvalho-Filho (Brazil) for providing literature and to S. Barbini who deposited the fish in the INIDEP collection. R. Wiff was funded by CONICYT CAPES FB-0002. We also express our gratitude to an anonymous referee for the valuable comments contributed on a previous draft of the manuscript. INIDEP contribution no. 2072.

\section{REFERENCES}

BALECH E. 1986. De nuevo sobre la oceanografía frente a la Argentina. Buenos Aires: Servicio de Hidrografía Naval. H645. 23 p.

BAlech E, Ehrlich MD. 2008. Esquema biogeográfico del Mar Argentino. Rev Invest Desarr Pesq. 19: 45-75.

Bernardes RA, Figueiredo JL, Rodrigues AR, Fischer LG, VOOREN CM, HAIMOVICI M, Rossi-Wongtschowski CLB. 2005. Peixes da Zona Econômica da Região Sudeste-Sul do Brasil: levantamento com armadilhas, pargueiras e rede de arrasto de fundo. São Paulo: EDUSP. 295 p.

Berry FH, Vogele LE. 1961. Filefishes (Monacanthidae) of the Western North Atlantic. Fish Bull. 61 (181): 61-109.

Carvalho-Filho, A. 1999. Peixes: Costa Brasileira. São Paulo: Melro. 320 p.

Cousseau MB, Bastida RO. 1976. Nuevas citas 
para la ictiofauna argentina y comentarios sobre especies poco conocidas. Physis (A). 35 (91): 235-252.

Cousseau MB, Figueroa DE. 1989. Peces de presencia ocasional en aguas marinas argentinas y uruguayas. Neotrópica. 35 (94): 121127.

Figueiredo JL, Menezes NA. 2000. Manual de peixes marinhos do sudeste do Brasil. VI Teleostei (5). Museu de Zoologia, Universidade de São Paulo. 116 p.

Figueroa DE, Díaz de Astarloa JM, Cousseau MB. 2000. Southernmost occurrence of the aguavina on the western Atlantic coast of Argentina. J Fish Biol. 56 (5): 1280-1282.

Froese R, Pauly D. 2015. FishBase [updated Feb 2015; accessed Feb 2015]. http://www.fishbase.org.

Guerrero RA, ACHA EM, FramiñAN MB, LASTA CA. 1997. Physical oceanography of the Río de la Plata estuary, Argentina. Cont Shelf Res. 17 (7): 727-742.

Irigoyen AJ, GaLvan D, Venerus L. 2005. Occurrence of dusky grouper Epinephelus marginatus (Lowe, 1834) in gulfs of northern Patagonia, Argentina. J Fish Biol. 67 (6): 1741-1745.

Izzo P, Milessi AC, Ortega L, Segura AM. 2010. First record of Aluterus scriptus (Monacanthidae) in Mar del Plata, Argentina. Marine Biodiversity Records. 3: e40.

Martos P, Piccolo MC. 1988. Hydrography of the Argentine continental shelf between $38^{\circ}$ and $42^{\circ}$ S. Cont. Shelf Res. 8 (9): 1043-1056.

Milessi AC, Colonello JH, Cortés F, Lasta CA, Waessle JA, Allega L. 2012. Extensión del límite austral de distribución de tres especies de peces óseos tropicales en la costa de la Provincia de Buenos Aires, Argentina. Lat Am J Aquat Res. 40 (4): 1061-1065.

Milessi AC, Bruno I, Spinedi M, Bernatene F, Garcia M, Cozzolino E, Carvalho-Filho A. 2017. Nuevos registros de peces tropica- les en la costa atlántica argentina. V Simposio Argentino de Ictiología, Corrientes, Argentina.

Milessi AC, Bruno I, Cozzolino E, Allega L, JaUReguizar AJ. 2018. Cambio climático global frente a las costas de Mar del Plata: evidencias de tropicalización? Inf Invest INIDEP N ${ }^{\circ}$ 131/2018. $10 \mathrm{p}$.

Moller O, Piola A, Freitas A, Campos E. 2008. The effects of river discharge and seasonal winds on the shelf off southeastern South America. Cont Shelf Res. 28 (13): 16071624

Ortega L, Celentano E, Delgado E, Defeo O. 2016. Climate change influences on abundance, individual size and body abnormalities in a sandy beach clam. Mar Ecol Prog Ser. 545: 203-213.

Scenna L, Segura V, Derisio C, Figueroa D, Díaz de Astarloa JM. 2006. First occurrence of common snook, Centropomus undecimalis (Centropomidae), in Argentinean waters. Cybium. 30 (2): 187-188.

Segura AM, Carranza A, Rubio Le, Ortega L, GARCía M. 2008. Stellifer rastrifer (Pisces: Sciaenidae): First Uruguayan records and a $1200 \mathrm{~km}$ range extension. Marine Biodiversity Records. 2: e67.

Trobbiani GA, Galván DE, Cuestas M, IrigoYEN AJ. 2014. Occurrence of the snowy grouper, Hyporthodus niveatus (Valenciennes, 1828), in Argentine waters. J Appl Ichthyol. 30 (1): 182-184.

Venerus A, Galván D, Irigoyen AJ, Gosztonyi A. 2007. First record of the namorado sandperch, Pseudopercis numida MirandaRibeiro, 1903 (Pinguipedidae; Osteichthyes), in Argentine waters. J Appl Ichthyol. 23 (1): 110-112.

Received: 24 June 2018

Accepted: 28 February 2019 